\title{
Interpreting Typical Profile of Transition Leaders - Case Croatia
}

\author{
Jasminka Samardžija
}

\begin{abstract}
The main goal of this empirical research was to define those crucial leadership characteristics and behaviours of experienced individuals that confirmed them as leaders in the Croatian transition economy, based on success of their entrepreneurial or social affirmations. The basic research question was: What is the empirical base for classifying leaders into homogeneous groups? Results of the general characteristics cluster analysis singled out three clusters Moderates, Internalists and Globalists. Inductive approach and supporting intermediate cluster analysis based on subjective dimension "career development expectations" aligned leaders from the sample in two homogenous groups: Leaders who seek self-actualisation and Leaders who seek for self-affirmation. Three clusters, Classical capitalists - materialists, Liberal capitalists - idealists and Capitalists non materialists were derived based on the confirmation of the personal success.
\end{abstract}

Keywords: Leadership characteristics; transition economy; career expectation; confirmation of success; transition leader profile

JEL Classification: $\mathrm{M} 12$

\section{Introduction and Theoretical Rationale}

Studies on leader traits - general characteristics distinguishing leaders from non-leaders or from ineffective leaders - can be traced back to 1869 , when Galton stated that leaders' traits were inherited and unchangeable (Galton, 1869; Zaccaro, 2007). Leadership studies need to go beyond existing contextual contingencies and incorporate multiple factors at a macro level including economic, social, and cultural changes (Shuang and Zhu 2015). The original interest and idea behind this research is to determine leadership characteristics that could be encouraged and developed during the education process in order to increase the number of future leaders. Despite the

\footnotetext{
* Jasminka Samardžija is at Rochester Institute of Technology Croatia, Zagreb, Croatia.
} 
growing mainstream literature on leadership, empirical research is yet to consolidate theories into a workable structure that provides guidance on the management of diverse expectations within a globalized business environment (Mintzberg, 2004). All leader-managers need to develop a global perspective or a global mindset (Beechler and Javidan 2007) and then we will be a step closer to the development of future Croatian leaders that will be able to impact GDP per capita via multiplying effects.

One particular type of leaders in recent times seems to achieve greater motivation and engagement among the workforce, focusing on transformative strength of the organization and relationship building among the employees of an organization (Bass and Riggio, 2006). Transformational Leaders are found to be inspirational and highly effective when it comes to increased motivation and positive outcomes (Bass and Riggio, 2006).

Trait theories gave rise to modern leadership research in the early 1900s, when leadership success was examined through leaders' demographic and physical traits, abilities, and personality characteristics (Bass, 1990; Stogdill, 1948). Funder's research proved that some leadership traits could be taught (Funder, 1991). Therefore, contemporary theory and research have shown a high interest for trait explanation of leadership (DeRue, Nahrgang,Wellman, and Humphrey, 2011). Leaders' stable traits are an important element in explicating their behaviors and outcomes (e.g., Eagly, 2007; Judge, Ilies, Bono and Gerhardt, 2002). According to the (Juras, 2010) it is empirically proved that respondents from Croatian companies consider that a high level of appropriate traits and skills is possessed, as well as that, depending on the context, appropriate leadership styles are applied. This indicates the development of consciousness related to the importance of leadership. In addition, demographic characteristics do not influence the respondents' awareness of the importance of effective leadership nor its further improvement for the benefit of the firm they work for.

A major advance in the mainstream leadership literature is a shift from a focus solely on leader attributes toward the interaction of leaders and followers, and leadership and its situational context (Dinh et al., 2014; Yukl, 2002). Therefore, leadership characteristics questionnaire used in this research made a step forward and was created using an inductive approach. All of the 44 descriptive adjective pairings of personal leadership characteristics were empirically derived from face-to-face life interviews with 100 Croatian leaders as well as corresponding notes and voice recordings of the interviews (Samardžija, 2013). Respondents were instructed to self-report their standing in regards to 42 descriptive adjective pairings of personal leadership characteristics.

\section{Data and Methodology}

The main research goal was to detect which characteristics a selected group of leaders find important, and then to identify those characteristics that should be reinforced 
during the education process, on the job training and organizational culture to enable a country in transition to better educate and encourage potential future leaders. Firstly, personal interviews with all 100 leaders were conducted (Samardžija, 2013). The research method used was the leader's life story. The idea was to interview different leaders of all ages, both gender, working in small and big businesses, but also leaders from a wide range of different fields of business. Therefore, the research sample included not only residents of the entire Croatian region but also exceptional expatriates. Specification of the number of interviewed leaders according to activity - field of interest is as follows: architecture and construction (5), banking (7), distribution \& trade (9), media \& publishing (10), researchers \& inventors (6), industrial production (9), non - profit organization (4), food industry (10), sport (11), tourism \& gastronomy (5), art (12) and 12 from science \& education. The goal was to determine common leadership characteristics based on a variety of leaders from different backgrounds. The interviews were conducted from July 2010 up until September 2013. Following this, all 100 respondents were surveyed through a combination of questionnaires distributed face-to-face, as well as online via Google form. The total number of respondents was 100 of whom 97 were valid. Females comprised $55.4 \%$ and males $44.6 \%$. 18.8\% of respondents were between the age of 18 and 29, the rest broken down as follows: $29.7 \%$ (30-39), 32.7\% (2049), $11.9 \%$ (50-59), $6.9 \%$ (60 and more). $26 \%$ established the company they work in, and $74 \%$ work for a company they did not establish. Forty eight percent of respondents reported growing up in towns; $12.7 \%$ in villages; $3.9 \%$ in cities (defined as $>1,000,000$ inhabitants), $4.9 \%$ in smaller places; $11.8 \%$ in hamlets, and $8.9 \%$ other. When asked: "How many times did you change your place of living?" $27.5 \%$ responded once, $29.4 \%$ twice, $19.6 \%$ three times, $10.8 \%$ four times and $12.7 \%$ five and more times. The extensive leadership personality traits questionnaire consisted of 50 questions in total. The foundation for the first part of the questionnaire testing the general characteristics is, The Big Five Model of Personality (Cronbach's Alpha $\alpha=.69$ ), which categorises traits into dimensions of surgency, agreeableness, adjustment, conscientiousness, and openness to experience (Lussier and Achua, 2016). During the course of the survey, respondents first rated 26 individual traits based on descriptive adjective pairings on a 5-point scale that best reflects their personality. The second pool of 44 leadership characteristics questionnaire (Cronbach's Alpha $\alpha=.93$ ) was created using an inductive approach. All of the 44 descriptive adjective pairings of personal leadership characteristics were empirically derived from face-to-face life interviews with 100 Croatian leaders as well as corresponding notes and voice recordings of the interviews (Samardžija, 2013). According to the descriptive statistics (mean) the top 10 leadership characteristics are as follows: conscientious (4.59), moral (4.56), persistent (4.54), love my job (4.50), hard-working (4.45), consistent (4.41), frank (4.33), seeing the "big picture" (4.28), professionally educated (4.24), physically non-aggressive (4.22). 
Purpose

The main goal of this empirical research was to define crucial personality traits and behaviour of experienced individuals that confirmed themselves as leaders in the transitional period of the Croatian economy based on success of their entrepreneurial and social affirmation. The purpose of this research was to detect and analyse traits and characteristics which best represent Croatian transition leaders and then to create and analyse clusters based on specific characteristics. The research goal was to create analysing groups and detect potential differentiation based on homogenous clusters. The focus research question is: What is the empirical base for classifying leaders into homogeneous groups? To answer this question three cluster analyses were conducted. Firstly, variables were grouped according to demographics, achievement, privacy and business including variables from the self-perception sphere; an applied cluster analysis procedure differentiated three homogenous clusters. The second cluster analysis was based on subjective dimensions of career expectations. The final cluster analysis was also based on subjective dimensions of confirmation of success, and results explained in details what our leaders see as confirmation of success.

\section{Results}

Cluster analysis as multivariate procedure enabled an objective inductive way of defining homogeneous groups of respondents based on a series of characteristics. This enabled empirically based classification, and made it possible to avoid speculative deductive categorisation, the halo effect, and other accompanying judgement errors of multiple criteria.

\section{Cluster Analysis of General Leadership Characteristics}

In this part of analysis, multiple classifications were performed based on general characteristics of our respondents related to their lives, work and business; what components were judged to be important for their personal lives perception successes; and compatibility of traits corresponding to their personalities. In cluster analysis we included 29 variables related to life, work and business, but after testing, an analysis of variance kept results of 24 variables for further consideration. Based on their contents, variables were grouped as follows: (6) demographic; (5) variables from achievements sphere; (5) privacy sphere; (5) business sphere; and (3) self-perception sphere. Applied cluster analysis procedure has differentiated three major groups (Table 1). 
Table 1: Cluster analysis of general leadership characteristics

\begin{tabular}{|c|c|c|c|c|}
\hline $\begin{array}{c}\text { Number of } \\
\text { the question } \\
\text { in the } \\
\text { questionnaire }\end{array}$ & VARIABLE/question content & $\begin{array}{c}\text { Cluster } 1 \\
\text { MODERATES }\end{array}$ & $\begin{array}{c}\text { Cluster } 2 \\
\text { INTERNALISTS }\end{array}$ & $\begin{array}{c}\text { Cluster } 3 \\
\text { GLOBALISTS }\end{array}$ \\
\hline \multicolumn{5}{|c|}{ DEMOGRAPHIC CHARACTERISTICS } \\
\hline 43 & Gender & Female & Male & Male \\
\hline 44 & Age & $20-49$ & $30-39$ & $50-59$ \\
\hline 47 & Where did you grow up? & Village & Multimillion city & City \\
\hline 49 & How many times have you moved? & One & Three & Four \\
\hline 35 & Was your mother employed? & Mostly yes & Yes & Yes \\
\hline 36 & Who was the dominant person in your family? & Grandfather & Father & Mother \\
\hline \multicolumn{5}{|c|}{ ACHIEVEMENT SPHERE } \\
\hline 2 & $\begin{array}{l}\text { At what age did you to take responsibility for self- } \\
\text { maintenance of your tasks? }\end{array}$ & $7-10$ & $15-18$ & $7-10$ \\
\hline 8 & $\begin{array}{l}\text { When did you notice that people would like to follow you } \\
\text { and that you can motivate people for activity? }\end{array}$ & $\begin{array}{c}\text { Elementary } \\
\text { school }\end{array}$ & High school & Elementary school \\
\hline 37 & How old were you when you first earned your money? & Less than 7 & $10-15$ & $10-15$ \\
\hline 45 & $\begin{array}{l}\text { When did you determine how you would develop your career } \\
\text { so that you could become whatever it is that you want to } \\
\text { ultimately be? }\end{array}$ & $\begin{array}{l}\text { After my college } \\
\text { degree }\end{array}$ & $\begin{array}{l}\text { After my college } \\
\text { degree }\end{array}$ & Elementary school \\
\hline 33 & Are you the owner of the company that you work for? & Partially & Majority owner & No \\
\hline \multicolumn{2}{|c|}{ PRIVACY SPHERE } & Not at all & 3 & Extremely \\
\hline 16 & Do you achieve work and rest balance? & 3 & 2 & 3 \\
\hline 17 & Do you achieve family and work balance? & 5 & 3 & 2 \\
\hline 27 & $\begin{array}{l}\text { Are you satisfied with the way you are spending your } \\
\text { vacation? }\end{array}$ & 2 & 4 & 4 \\
\hline 28 & Do your daily activities deplete you? & 2 & 4 & 5 \\
\hline 42 & Do you dream about your job? & No & Yes & Yes \\
\hline \multicolumn{2}{|c|}{ BUSINESS SPHERE } & Not at all & 3 & Extremely \\
\hline 19 & Do you achieve international cooperation? & 3 & 1 & 4 \\
\hline 20 & Do you learn from the best world praxis in your area? & 4 & 1 & 5 \\
\hline 21 & Are you a source of best praxis in your area? & 4 & 1 & 5 \\
\hline 22 & $\begin{array}{l}\text { Do you apply modified international praxis while doing } \\
\text { business in Croatia? }\end{array}$ & 4 & 1 & 5 \\
\hline 23 & $\begin{array}{l}\text { To what extent do international markets influence your } \\
\text { daily business? }\end{array}$ & 3 & 1 & 5 \\
\hline \multicolumn{5}{|c|}{ SELF-PERCEPTION } \\
\hline 29 & Would you call yourself a workaholic? & Not at all & To a certain extent & Yes \\
\hline 30 & Do your peers/colleagues see you as workaholic? & Not at all & Yes & Yes \\
\hline \multirow[t]{3}{*}{40} & $\begin{array}{l}\text { Do you perceive yourself as different from the rest of the } \\
\text { people? }\end{array}$ & To certain extent & A bit & Yes, very different \\
\hline & SUM of respondents n=97 & 22 & 23 & 52 \\
\hline & Percentages & $22.7 \%$ & $23.7 \%$ & $53.6 \%$ \\
\hline
\end{tabular}

Source: Author's research 
The first cluster (Cluster 1) covered $22.7 \%$ of leaders respondents. The important demographic characteristic of our first cluster is that most of them were raised in a village in a family where the mother was employed most of the time and the dominant family figure was the grandfather. Those leaders started to take responsibility for the execution of their tasks early in their childhood, between 7-10 years old, and they earned their first money when they were 7 years old. Already in elementary school they noticed that people are willing to follow them, but they discovered their life career determination and what they ultimately want to become later in their lives, precisely right after they finished college. Now, they are partial owners of the company they work for. In the privacy sphere, they are satisfied with their family and work balance, but moderately with work and rest balance. They are not satisfied with the way they spend their vacation at all, neither with the fact that daily activities deplete them. They do not dream about their jobs. As far as the business sphere is concerned, they moderately evaluate their international collaboration because the influence of the foreign markets on their business does not concern them much. On the other hand they are able to learn from the world praxis a lot. They are able to modify and apply world praxis in Croatia. They are not perceived as workaholics, neither personally nor from their social environment. To a certain extent they see themselves different from other people. Due to their middle position and the moderate influence of foreign markets on their business performance, this cluster is named Moderates.

The second cluster (Cluster 2) covered $23.7 \%$ of leaders from the sample. Mainly comprising of man ranging from 30-39 years old, who were born and grew up in a big city, whose mother was permanently employed and whose dominant family figure was their father. They earned their first money aged 10-15, but in adolescence they started to take responsibility for the independent execution of their tasks, and in high school they noticed their ability to motivate others to follow them. After finishing college they discovered their future career determination, and now they are major owners of the companies they work for. They are markedly unhappy because they do not achieve work and a rest balance, but are a bit less concerned about not achieving family/work balance.

They are extremely happy with the way they spend their vacations, but daily activity exhausts them. They do not dream their jobs. Regarding the business sphere, they do not apply modified international praxis while doing business in Croatia, nor did they achieve international cooperation. They do not follow or learn anything from the best world's praxis, probably because foreign markets do not influence their businesses at all. They think of themselves as partially workaholics, and others have similar opinions of them; additionally they think they are slightly different from the rest of people. We could call this group of leaders Internalists, because they do not have contacts with foreign markets and they do not learn from world's best praxis.

The third cluster (Cluster 3) covers more than half of the leaders from our sample (53.6\%). In this group sample prevail men aged 50-59 years old, who were born and 
raised in the city, and whose families moved four times. Their mother was employed full time, and was the dominant family figure. In their early childhood (ages of 7-10), they started to take responsibility for self-execution of their tasks, but they earned their first money only at the age of 10-15, much later than the leaders from the first cluster. In elementary school, they noticed that others were willing to follow them. They are especially differentiated from leaders of Clusters 1 and 2, due to the fact that they discovered early in elementary school what they would like to become in the future. In the privacy sphere, they are moderately satisfied with the work and rest balance. Compared to the leaders from the first and second clusters, they are the least satisfied with family and business balance. Daily based business activities deplete them, and they do dream about their jobs. They are mostly focused on international collaboration and think that they learn from international praxis a lot and subsequently applying modified international business praxis to the Croatian market, a result of their belief is that foreign markets have an extreme influence on their businesses. They think of themselves as workaholics and that they are perceived as such by their colleagues. These leaders consider themselves very different from others, respectively, they experience their leadership as a dispositional social role. We could call this group of leaders Globalists, because they contact, learn and apply achievements of world's best praxis in their work and businesses.

\section{Leader Classification Based on Subjective Dimensions}

\section{Career Development Expectations}

This cluster analysis proved that leaders from our sample exclusively dichotomous rated factors important for the development of their career. Inductive approach and supporting intermediate cluster analysis based on subjective dimension "career development expectations" aligned leaders from our sample in two homogenous groups (Table 2).

The first cluster covers first half of leaders (51\%) which are characterised exclusively by intrinsic motivation. They see "love towards their job and profession" and "possibility to use all of their special talents" as extremely important (5) and a bit less important (4) "to have an opportunity to create a new entity (organization) as well as "to develop new products or services". A sense of safeness/stability "that I feel safe and financially secure" is likewise moderately important "to overcome impossible obstacles; that I solve unsolvable problems or achieve victory over strong competition" which was graded 3 on the Likert scale. They perceive the earnings and social prestige, opportunity to lead and all the other listed extrinsic and intrinsic incentives less important or not important at all. Autonomy and independence is moderately important and therefore we could conclude that they would like to have a sort of stable frame in which they could create new products and services. To conclude with 
we could call this group "Leaders who seek intellectual self-actualisation" (latin; actualis, practical, actual).

Table 2: Cluster analysis of career development expectations - initial cluster centres

\begin{tabular}{|c|c|c|}
\hline \multirow[t]{2}{*}{ For development of my career, it is important: } & $\begin{array}{l}\text { Initial clu } \\
\text { Not } 123 \\
\text { important }\end{array}$ & $\begin{array}{l}\text { ter centres } \\
5 \quad \text { Extremely } \\
\text { important }\end{array}$ \\
\hline & $\begin{array}{l}\text { Cluster } 1 \\
\text { Leaders who seek } \\
\text { self-actualisation }\end{array}$ & $\begin{array}{c}\text { Cluster } 2 \\
\text { Leaders who seek } \\
\text { for self-affirmation }\end{array}$ \\
\hline $\begin{array}{l}\text { To be (stay) in a company older and more experienced than } \\
\text { myself }\end{array}$ & 1 & 5 \\
\hline $\begin{array}{l}\text { That my superior gives me a chance for self-affirmation and that } \\
\text { he believes in me }\end{array}$ & 1 & 5 \\
\hline That I specialize and develop in my field of expertise & 3 & 5 \\
\hline That I have a clear wish to climb the corporate ladder & 2 & 5 \\
\hline $\begin{array}{l}\text { To have an opportunity to create a new entity (organization) as } \\
\text { well as to develop new products or services }\end{array}$ & 4 & 5 \\
\hline $\begin{array}{l}\text { That I have autonomy and independence - I can work at my own } \\
\text { pace, according to my personal standards and conditions and } \\
\text { within my personally defined time frames }\end{array}$ & 3 & 5 \\
\hline $\begin{array}{l}\text { That I have a sense of safeness/stability - that I feel safe and } \\
\text { financially secure }\end{array}$ & 3 & 5 \\
\hline $\begin{array}{l}\text { That I integrate my professional life and career with my personal } \\
\text { life and future family needs - life balance matters }\end{array}$ & 2 & 5 \\
\hline $\begin{array}{l}\text { That I make the world a better place, improving and serving } \\
\text { society }\end{array}$ & 3 & 5 \\
\hline $\begin{array}{l}\text { That I overcome impossible obstacles; that I solve unsolvable } \\
\text { problems or achieve victory over strong competition }\end{array}$ & 3 & 5 \\
\hline That I love my job and profession & 5 & 5 \\
\hline That I use all of my special talents & 5 & 5 \\
\hline That my job gives me an opportunity to be financially well-off & 2 & 5 \\
\hline That my job provides me with high social status and prestige & 2 & 5 \\
\hline $\begin{array}{l}\text { That my job gives me numerous opportunities to work with } \\
\text { people }\end{array}$ & 2 & 5 \\
\hline That my job gives me the option to lead and manage others & 1 & 5 \\
\hline Percentages \% & 1 Cluster $51 \%$ & 2 Cluster $49 \%$ \\
\hline
\end{tabular}

Source: Author's research

The second cluster presents homogeneous group of the other half of leaders (49\%) who see all of the listed intrinsic and extrinsic variables as extremely important (5) for their career development according to the results we could call this group "Leaders who seek for self-affirmation". Ad plus firmus (Latin) adjective stable, strong, firm affirmation $=$ a positive assertion. The crucial difference between Leaders who seek intellectual self-actualisation and Leaders who seek for self-affirmation is in 
the intrinsic motivation that prevails in first cluster and dominates it. Intrinsic motivation is doubtlessly important but without autonomy and focus on improving and serving society or extrinsic components career development globally not much can be changed.

\section{Confirmation of My Personal Success}

The following table (Table 3) presents the cluster analysis results, showing the answers to the following questions: What presented confirmation of success according to leaders sample answers? Was there a different homogenisation of our leaders sample based on that question?

Table 3: Cluster analysis - Confirmation of my personal success

\begin{tabular}{|c|c|c|c|}
\hline \multirow{3}{*}{ Confirmation of my personal success is: } & \multicolumn{3}{|c|}{ Initial cluster centres } \\
\hline & \multicolumn{2}{|l|}{$\begin{array}{l}\text { Not } \\
\text { important } \\
\end{array}$} & $\begin{array}{l}\text { Extremely } \\
\text { important }\end{array}$ \\
\hline & $\begin{array}{c}\text { Cluster } 1 \\
\text { Classical } \\
\text { capitalists - } \\
\text { materialists }\end{array}$ & $\begin{array}{c}\text { Cluster } 2 \\
\text { Liberal } \\
\text { capitalists - } \\
\text { idealists }\end{array}$ & $\begin{array}{c}\text { Cluster } 3 \\
\text { Capitalist non } \\
\text { materialists }\end{array}$ \\
\hline The amount of profit that I have earned & 5 & 5 & 1 \\
\hline High society affiliation & 2 & 5 & 1 \\
\hline A satisfied team of employees & 4 & 5 & 5 \\
\hline Being discussed in the media & 1 & 5 & 1 \\
\hline Being part of government policy formation & 1 & 5 & 1 \\
\hline How many homes or properties I own & 5 & 5 & 1 \\
\hline The number of cars that I have & 3 & 5 & 1 \\
\hline The number of people we employ & 4 & 5 & 1 \\
\hline The market share of our services and products & 4 & 5 & 3 \\
\hline The number of foreign markets that we are present at & 1 & 5 & 3 \\
\hline Team commitment and good human relationships & 4 & 5 & 4 \\
\hline That I stayed the same uncorrupted person as I used to be & 3 & 5 & 5 \\
\hline Successful family life & 4 & 5 & 5 \\
\hline Having good health & 3 & 5 & 5 \\
\hline Being able to actively play and engage in sports & 3 & 5 & 4 \\
\hline $\begin{array}{l}\text { Leaving a positive mark on society; making the world a } \\
\text { better place }\end{array}$ & 1 & 5 & 5 \\
\hline Enabling my children to obtain a college level of education & 4 & 5 & 4 \\
\hline Percentages \% & 1 Cluster $24 \%$ & 2 Cluster $46 \%$ & 3 Cluster $30 \%$ \\
\hline
\end{tabular}

Source: Author's research

The first cluster homogenised one quarter of leaders which perceive extremely important: amount of profit earned, number of homes or properties, but they find 
moderately important number of cars as a visible sign of prestige. They consider important (4) satisfied team of employees they work with as well as the number of people they employ and value high market share of their products and services. As opposed to that they do not consider belonging to high society important rated (2). Confirmation of their personal success does not present media presence nor creation or being part of government policy formation, therefore leaders of this cluster graded it as not important.

Due to the highly expressed common characteristics we could call them Classical capitalists - materialists who are exclusively oriented on high profit achievement which is then mostly converted into homes and properties, and a smaller portion into cars probably not to potentially attract media attention. Neither leaving a positive mark on society, nor making world a better place or any kind of political engagement, is of their primary interest.

The second cluster covers the largest number of leaders from our sample who see all targets and instrumental forms of their affirmation in business and private social environment as extremely important. Therefore, leaders from the second cluster were named Liberal capitalists - idealists oriented on winning all possible extrinsic contents and using all instrumental ways of meeting the intrinsic needs and aspirations. For them, it is equally important generating huge profit, their material enrichment, social recognition and prestigious external signs, and, on the other hand, they see team affection and wish to stay the same person as they always were extremely important as well.

The third cluster covers one third of leaders from our sample, who, according to their statements, see all material symbols and extrinsic incentive completely unimportant for confirmation of its personal success. A confirmation of their personal success represents a satisfied team of employees, balanced and successful family life, active sports engagement and good health, and the fact that they stayed the same uncorrupted person as they used to be. They consider leaving a positive mark on society and making the world a better place as extremely important. Therefore this cluster was labelled by illogical syntagmatic phrase Capitalist non materialists.

\section{Application of Cluster Analysis of Transition Leaders - Case Croatia}

According to the Cluster analysis of general leadership characteristics the third cluster (Cluster 3 - Globalists) covers more than half of the leaders from our sample (53.6\%). In this group sample prevail men aged 50-59 years old, who were born and raised in the city, and whose families moved four times. Their mother was employed full time, and was the dominant family figure. In their early childhood (ages of 7-10), they started to take responsibility for self-execution of their tasks, but they earned their first money only at the age of 10-15, much later than the leaders from the first 
cluster. In elementary school, they noticed that others were willing to follow them. They are especially differentiated from leaders of Clusters 1 and 2, due to the fact that they discovered early in elementary school what they would like to become in the future. Since Globalists cluster represents majority of leaders therefore we could say that their characteristics represent a psychological profile of a transition leader. Transition leader is focused on international collaboration, open to the global world and learns from international praxis, subsequently applying modified international business praxis to the Croatian market. Foreign markets extremely influence his businesses. Additional working hours are a precondition of success of future Croatian leaders because an organization is formed to achieve certain goals and objectives by bringing individuals together on a common platform and leader motivates, defines and shapes working culture that should be followed.

According to the research leaders consider themselves different than other people and they are aware of it. Those characteristics and diversity should be encouraged in society during education process but also later in the workplace since transition leaders experience their leadership as a dispositional social role. If Croatia is willing to improve its economic indicators starting with GDP per capita, there is an urgent need to create more future leaders - Globalists. Improving defined leadership characteristics by making them one of the outcomes of education process, and to additionally improve those skills later by on the job training. That effort could potentially bring positive outcomes to the overall Croatian society.

Inductive approach and supporting intermediate cluster analysis based on subjective dimension "career development expectations" aligned leaders from our sample in two homogenous groups: Cluster 1 leaders who seek self-actualisation and Cluster 2 leaders who seek for self-affirmation. Transition leaders from the second cluster consider all of the listed intrinsic factors such as: I specialize and develop in my field of expertise; I have a clear wish to climb the corporate ladder; I have autonomy and independence; I love my job and profession as extremely important. On the other side extrinsic variables were also identified as extremely important for career development of leaders who seek for self-affirmation. While intrinsic motivation prevails in the first cluster it is balanced with extrinsic in the second cluster. Therefore, we could conclude that intrinsic motivation is doubtlessly important but without autonomy and focus on improving and serving society or extrinsic components career development globally not much can be changed.

Confirmation of my personal success homogenised three clusters: Classical capitalists - materialists, Liberal capitalists - idealists, Capitalists non materialists. Liberal capitalists cluster covers the largest number of leaders from our sample who see all targets and instrumental forms of their affirmation in business and private social environment as extremely important. For them, it is equally important generating huge profit, their material enrichment, social recognition and prestigious external signs, and, on the other hand, they see team affection and wish to stay the same 
person as they always were extremely important as well. We could name it a positive heritage of the communist system in the former Yugoslavia that was operating under a self-management system with many elements of a market economy but the other part of the answer and cluster differentiation could be found in religion that had enormous impact on the organization of social and economic life of many societies throughout modern history (McNeill, 1963; Huntington, 1996) but influences Croatian presence as well. For example, what many refer to as modern Western civilization is often defined in terms of an overarching and pervasive Judeo-Christian value system giving character to a broad culture and society in terms of its religious heritage and tradition. However, Christianity, as the dominant religion of Western civilization, is itself multifaceted with important differences among its various denominations. These differences include attitudes towards free enterprise, private ownership, and individual freedom - all of which directly affect general attitudes towards entrepreneurship (Mueller and Goic, 2002) and consequently leadership traits as well.

To conclude with there is still not fully acceptable to differentiate from the others much, nor to achieve visible result that has a broad impact on personal life and consequently society. On the other side the highest percentage $46 \%$ of leaders belong to Liberal capitalists - idealists those that believe that it is possible to achieve confirmation of personal success in all three areas: personal, professional and to give back to society what is takes by making world a better place. This could be perceived as a positive heritage of the former socialist system that Croatia was part of and the open question is: Is it really possible to achieve such a balance? If yes than Croatia could present a role model for life and work balance but according to the first cluster Globalists are, in the privacy sphere, moderately satisfied with the work and rest balance and in comparison with Moderates and Internalists, they are the least satisfied with family and business balance because daily based business activities deplete them, and they do dream about their jobs.

\section{Limitations and Future Research}

This research was limited to Croatia and it would be interesting to conduct a comparative analysis of psychological profile of leaders from other European transition economies but also compare leadership characteristics of emerging Asian economies. On the other side, future research goal could go towards comparing psychological profile of leaders from developed European economies (Germany, Norway, and Switzerland), but also leaders from United States. 


\section{Conclusion}

To understand development of a more comprehensive and updated understanding of business leadership presumption is that leadership dynamics involves the interaction of micro-level variables, including cognition and perception as well as macro-level variables, such as economic, social, and cultural transition; and leadership perception and practices vary within a single geographic/cultural entity (Ren \& Zhu, 2015)

Improving defined leadership characteristics by making them one of the outcomes of education process, and to additionally improve them later by on the job training could potentially bring positive outcomes to the overall Croatian society. For career development of "Leaders who seek for self-affirmation" intrinsic and extrinsic variables are equally important and society should encourage that approach and offer incentives in material and nom material form.

Respondents from Croatian companies consider that a high level of appropriate traits and skills is possessed, as well as that, depending on the context, appropriate leadership styles are applied (Juras, 2010). This indicates the development of overall consciousness related to the importance of leadership. Transformational leaders are creative, energetic, team players, and at the very core of the transformational leadership model one can find consciousness - of self and of others. The change towards this type of leadership has to start at the individual level and it should continue to interpersonal relationships and finally to the organization as a whole (Hacker \& Roberts, 2003).

In addition, demographic characteristics do not influence the respondents' awareness of the importance of effective leadership nor its further improvement for the benefit of the firm they work for but to conclude with it is indicative that $53.6 \%$ of all leaders respondents belong to the Globalist cluster. On the other side there is also a huge potential of the leaders that belong to the Internalist cluster $(23.7 \%)$. If they would open their minds to the external, world praxis and enable international markets to influence their daily business that could improve self-perception of Internalists cluster and their capabilities and subsequently have potential impact on GDP. This could be reinforced through international education, MBA-s that encourage sharing of best practice and educations that are case study based, promote visiting international fairs, and industry based conferences as well as non-formal education that shares the world's best praxis. 


\section{REFERENCES}

Bass, B. M., (1990), Bass \& Stogdill's handbook of leadership: Theory, research, and managerial applications (3rd ed.), New York: Free Press

Bass, B.M. and Riggio R.E. (2006), Transformational Leadership (2nd ed.). Mahwah, NJ: Lawrence Erlbaum.

Beechler, S., Javidan, M., (2007), Leading with a global Mindset, In Javidan, M., Hitt, M.A., and Steers, R.M. (eds) 2007, The Global Mindset, Elsevier.

DeRue, D. S., Nahrgang, J. D., Wellman, N., \& Humphrey, S. E.,(2011), Trait and behavioral theories of leadership: An integration and meta-analytic test of their relative validity, Personnel Psychology, 64, 7-52.

Dinh, J.E. , Lord, R.G. , Gardner, W.L. , Meuser, J.D. , Liden, R.C. and Hu, J. (2014), Leadership theory and research in the new millennium: current theoretical trends and changing perspectives, Leadership Quarterly, Vol. 25 No. 1, pp. 36-62.

Eagly, A. H., (2007), Female leadership advantage and disadvantage: Resolving the contradictions, Psychology of Women Quarterly, 31(1), 1-12.

Funder, D.C., (1991), Global traits: A neo-allportian approach to personality, Psychological Science, 2(1), 31-39.

Galton, F., (1869), Hereditary genius, New York: Appleton

Hacker, S. \& Roberts, T. (2003) Transformational Leadership: Creating Organizations of Meaning. Milwaukee, WI, USA: ASQ Quality Press.

Judge, T. A., Ilies, R., Bono, J. E., Gerhardt, M. W., (2002), Personality and leadership: A qualitative and quantitative review, Journal of Applied Psychology, 87, 765-780.

Judge, T. A., Long, D. M., (2012), Individual differences in leadership. In D. V. Day, \& J. Antonakis (Eds.), The nature of leadership (pp. 179-217), (second edition), Thousand Oaks, CA: Sage Publications, Inc.

Juras, Ana., (2010), Traits, skills and leadership styles of managers in Croatian firms, Management : Journal of Contemporary Management Issues, 67-84.

Lussier, R., Achua, C., (2016), Leadership: Theory, application, \& skill development, $6^{\text {th }}$ edition, Cengage Learning.

McNeill, W. H., (1963), The rise of the West. Chicago, IL: University of Chicago Press.

Offermann, L. R., Kennedy, J. K., \& Wirtz, P. W., (1994), Implicit leadership theories: Content, structure, and generalizability, The Leadership Quarterly, 5(1), 43-58.

Mueller, Stephen L., and Srecko Goic., (2002), Entrepreneurial Potential in Transition Economies: A View from Tomorrow's Leaders, Journal of Developmental Entrepreneurship, (2002): 399-414.

Mintzberg, H. (2004), Managers not MBAs: Berrett-Koehler Publishers Inc., San Francisco, CA.

Samardžija, J., (2013), Intervjui sa 100 hrvatskih lidera o životu i razvoju karijere, Zagreb: Motivacijski govornik.

Ren, S., Zhu, Y., (2015), Making sense of business leadership vis-à-vis China's reform and transition, Leadership \& Organization Development Journal, Vol. 36, no. 7. (pp. 867-884).

Stogdill, R. M., (1948), Personal factors associated with leadership; a survey of the literature. Journal of Psychology: Interdisciplinary and Applied, 25, 35-71.

Yukl, G. (2002), Leadership in Organizations, Prentice Hall, Upper Saddle River, NJ.

Zaccaro, S.J., (2007), Trait-based perspectives of leadership, American Psychologist, 62(1), 6-16. 